\section{Kontak Bahasa yang Terepresentasi di Nama- Nama Tokoh Hikayat Raja Pasai}

\author{
Nadhifa Indana Zulfa Rahman \\ Graduate Program of Linguistics \\ Universitas Gadjah Mada \\ nadhifazulfa95@gmail.com
}

\begin{abstract}
ABSTRAK
Penelitian ini bertujuan untuk menjelaskan sistem penamaan tokoh yang disebutkan dalam Hikayat Raja Pasai sebagai perwujudan atas isu kontak bahasa yang dialami masyarakat Pasai pada masa itu. Metode penelitian yang dilakukan ada tiga tahap, yaitu metode pengumpulan data, metode analisis, dan metode penyajian hasil analisis. Metode pengumpulan data dilakukan dengan metode simak bebas libat cakap dengan teknik lanjutan teknik catat. Metode analisis data dilakukan dengan metode padan referensial dan metode padan translasional. Selanjutnya, penyajian hasil analisis dilakukan dengan kata-kata biasa. Berdasarkan hasil analisis, dapat disebutkan bahwa sistem penamaan masyarakat Pasai di masa lalu merupakan dampak dari adanya kontak bahasa. Konstruksi bahasa yang digunakan dalam penamaan tokoh dalam Hikayat Raja Pasai ada beberapa model, yaitu 10 nama menggunakan BA, 14 nama tokoh menggunakan BM, dua nama menggunakan campuran BA dan BS, satu nama menggunakan campuran BA dan BT, tujuh nama menggunakan campuran BS dan BM, dua belas nama menggunakan campuran BA dan BM, satu nama menggunakan campuran BS dan BK, satu nama menggunakan campuran BA dan modifikasi BA ke BM, empat nama menggunakan campuran BM dan BK, satu nama menggunakan campuran BK dan modifikasi dari BA ke BM, satu nama menggunakan campuran BA dan perpaduan $\mathrm{BH}$ dan $\mathrm{BA}$, satu nama menggunakan campuran BA dan perpaduan BM dan BA, satu nama menggunakan campuran BM dan modifikasi BA ke BM, satu nama menggunakan campuran BB dan BM, satu nama menggunakan campuran BK, BS, dan BM dan satu nama dengan menggunakan campuran BC dan BM.
\end{abstract}

Kata kunci: Hikayat Raja Pasai; kontak bahasa; sistem penamaan; asal bahasa

\title{
PENDAHULUAN
}

Masyarakat dan bahasa adalah dua hal yang saling memengaruhi. Keduanya juga sama-sama bersifat dinamis seiring dengan perkembangan zaman. Pada era 6oan, masyarakat Indonesia, misalnya, belum mengenal leksikon laptop karena benda canggih itu belum dikomersialkan. Oleh karena itu, di tahun 2019 ini, ketika ada seorang remaja berusia 17 tahun sedang membicarakan masalah laptop dengan neneknya yang pendidikan terakhirnya SMP dan kini berusia 80 tahun akan muncul kesenjangan informasi. Neneknya mungkin tidak mengerti laptop itu mengacu pada benda yang seperti apa. Melalui fenomena tersebut, diasumsikan bahwa seseorang berbicara dengan bahasa seperti yang ia gunakan saat dalam usia produktifnya. Dengan demikian, bahasa yang digunakan seseorang bisa menjadi suatu potret sejarah dan budaya pada kurun tertentu.

Salah satu dokumentasi budaya dan sejarah suatu masyarakat adalah hikayat. Karya-karya dengan kandungan informasi mengenai masa lampau itu tercipta dari latar sosial budaya yang tidak ada lagi atau yang tidak sama dengan latar sosial budaya masyarakat pembaca masa kini (Baroroh-Baried dkk., 1994: 1). Baroroh-Baried dkk. (1994: 1) menyebutkan,

Berbeda dengan produk sastra modern, hasil ciptaan masa lampau berada dalam kondisi yang tidak selalu dapat diterima dengan jelas dan sering dikatakan "gelap" atau "tidak jelas" oleh pembaca masa kini sehingga banyak karya tulisan masa lampau dirasakan tidak mudah dipahami

Hal itulah yang kemudian mendasari karya sastra kuno ini mendapat sedikit perhatian. Oleh karena itu, penelitian dengan menggunakan naskah-naskah kuno harus lebih banyak dilakukan agar nilai-nili yang ada di dalamnya dapat diinfromasikan secara tepat ke pembaca masa kini. Apalagi, karya sastra 
tersebut merupakan manifestasi pikiran, gagasan, dan juga rekaman peristiwa sejarah, sosial, dan budaya di masa karya sastra tersebut dituliskan atau bahkan sebelumnya.

Objek material dalam penelitian ini bersumber dari Hikayat Raja Pasai. Hikayat Raja Pasai yang digunakan dalam penelitian ini adalah hikayat yang telah ditransliterasikan oleh Russell Jones (1999). Sumber data yang dipilih tersebut merupakan karya kuno yang menurut Liaw Yock Fang (2011: 436), merupakan hasil sastra sejarah tertua yang menceritakan peristiwa yang terjadi antara tahun 12501350. Winstedt (dalam Liaw Yock Fang, 2011: 436) menyimpulkan bahwa Hikayat Raja Pasai ditulis pada abad ke-14. Hikayat Raja Pasai dianggap sebagai karya sastra lama yang kanon. Artinya, karya ini orisinil dan sangat fenomenal di masanya sehingga menginspirasi penulis-penulis lain.

Hikayat ini dimasukkan dalam kategori sastra sejarah oleh para ahli Filologi, salah satunya Liaw Yock Fang (1975: 204). Oleh karena itu, hikayat ini menjadi sumber sejarah yang berharga. Hikayat juga mengandung informasi kebahasaan yang mungkin berbeda dengan masa kini. Berbeda dengan karya sastra yang bersifat imajinatif lainnya, sastra sejarah memiliki kandungan historis di dalamnya. Kandungan historis itu dapat terefleksi pada penamaan tokoh-tokohnya, peristiwa, dan nama tempat. Karena nama tokoh-tokoh di dalam hikayat ini dinilai cukup logis dan representatif, peneliti memilih hikayat ini sebagai sumber data untuk mengamati sistem penamaan masyarakat Pasai di masa lalu.

Penelitian mengenai sistem penamaan diri ini sudah banyak dilakukan. Pertama, terdapat penelitian yang dilakukan Wibowo (2001) yang berjudul "Nama Diri Etnik Jawa". Wibowo (2001: 53) menyebutkan dalam penelitian tersebut menyebutkan bahwa suku akhir komponen nama dapat menandai gender. Selain itu, tujuan penamaan bisa beragam, yaitu mengandung harapan, cita-cita, dan menggambarkan aspek historisitas kelahiran. Fungsi-fungsi penamaan tersebut secara esensial digunakan sebagai penanda identitas seseorang dalam masyarakat dan juga berfungsi sebagai upaya pemenuhan kebutuhan situasional/ kondisional, misalnya penghormatan, penandaan urutan, penanda jenis kelamin, keakraban, kerahasiaan.

Penelitian mengenai sistem penamaan etnik yang lain ditulis oleh Siswanto (2012) berjudul "Pengulangan Bunyi Nama Diri pada Masyarakat Sunda". Penelitian ini menghasilkan deskripsi mengenai fenomena pengulangan bunyi yang sama pada nama diri masyarakat Sunda. Pengulangan tersebut terjadi antara salah satu silabel nama depan dengan salah satu silabel nama belakangnya. Dari 18 pola pembentukan nama diri yang ditemukan, pengulangan bunyi bersilabel satu lebih banyak digunakan daripada yang bersilabel dua. Menurut Siswanto (2010: 72), hal ini menunjukkan bahwa masyarakat Sunda menyukai kesederhanaa.

Selanjutnya, terdapat penelitian dari Sariah (2012) yang berjudul "Antroponimi dalam Obituari Keturunan Tionghoa: Sebuah Tinjauan Deskrptif." Berdasarkan hasil analisis yang telah dilakukan, rata-rata konstruksi antroponimi Tionghoa terdiri dari tiga unsur, yaitu nama keluarga/marga, status marga, dan nama utama. Selanjutnya, menanggapi adanya peraturan pemerintah 127/U/Kep/12/1966, masyarakat Tionghoa memakai nama Indonesia dan nama Tionghoa sekaligus. Budaya menjadi faktor yang mempengaruhi masyarakat dalam memilih ganti nama Tionghoanya menjadi nama Indonesia. Pada era yang lebih modern, anak-anak keturunan Tionghoa banyak memakai nama asing (baptis/ Eropa).

Tiga artikel di atas merupakan beberapa hasil penelitian mengenai penamaan diri yang relevan untuk dibahas di dalam penelitian ini. Yang membedakan penelitian ini dengan penelitian-penelitian sebelumnya ialah sumber data. Data penelitian sebelumnya didapatkan dari instansi pemerintahan atau lainnya, sedangkan penelitian ini datanya bersumber dari hikayat yang berjudul Hikayat Raja Pasai.

Nama diri bisa menjadi identitas individu dan kelompok masyarakat yang mencerminkan kekhasan. Dengan demikian, jika berkenalan dengan orang baru, nama orang tersebut berawalan Teuku atau Cut, kita bisa mengasosiasikan secara umum daerah asal orang tersebut. Selain itu, nama juga bisa berupa doa atau harapan. Misalnya, seorang bayi yang baru lahir dinamai Tulus. Harapannya, kelak anak tersebut tumbuh menjadi seorang manusia yang memiliki sifat demikian. Penamaan diri juga bisa dipengaruhi oleh ciri fisik tertentu seseorang, misalnya Edy Gendut Sutanto yang merujuk pada bentuk fisiknya. 
Dengan demikian, karena penelitian ini menekankan pada penamaan diri, dibutuhkan teori onomastik sebagai landasan. Onomastik adalah suatu ilmu dalam linguistik untuk mengkaji penamaan diri. Nama diri merupakan sebuah produk sosial yang artinya, nama berasal dari norma, konvensi sosial, semangat kebersamaan, mitos, dan seleksi kultural yang muncul dari pemberi nama (Aribowo dan Nanik Herawati, 2016: 271). Nama diri diasumsikan memiliki makna dan fungsi yang berbeda satu dengan yang lain di lingkungan sosial masyarakat. Hal itu sejalan dengan yang disampaikan Blanár (2009: 92) bahwa:

"The basic questions of onomastics, such as the character of a proper name, its onymic meaning and content, onymic functions, onymic system and its functions in social communication, are the subjects of research of general linguistics, the theory of communication and the theory of onomastics."

Sebelum agama Islam masuk ke Pasai, penamaan diri masyarakat Pasai cenderung menggunakan bahasa Melayu yang terpengaruh bahasa lainnya seperti Sansekerta dan Kawi. Namun, ada dua nama diri yang tidak sesuai dengan pendapat di atas. Raja Ahmad dan Raja Muhammad merupakan dua bersaudara yang menjadi kakek dari Raja Pasai yang pertama, Malikul Saleh. Jika menilik dari hikayat, Islam masuk saat Pasai dipimpin oleh Malikul Saleh. Dengan demikian, seharusnya Raja Ahmad dan Raja Muhammad tidak termasuk dalam era Islamisasi tersebut. Namun demikian, salah satu ciri sastra sejarah adalah biasanya merupakan pesanan dari raja yang berkuasa. Oleh karena itu, isi hikayat ini banyak mengagung-agungkan kemegahan raja dan nenek moyangnya. Bisa jadi, Raja Ahmad dan Raja Muhammad adalah salah satu strategi Pasai untuk mencitrakan rajanya sebagai keturunan raja yang baik yang bahkan namanya terinspirasi dari nama tokoh penting agama Islam, yaitu Nabi Muhammad SAW.

Oleh karena adanya fenomena perubahan nama dari bahasa Melayu ke bahasa Arab tersebut, dapat dikatakan bahwa masyarakat Pasai mengalami kontak bahasa dalam kehidupan sosial masyarakatnya. Peristiwa kontak bahasa adalah hal yang tidak bisa dielakkan terlebih oleh masyarakat daerah pesisir yang menjadi jalur perdagangan teramai di Nusantara pada masa itu. Kontak bahasa terjadi saat para pedagang asing masuk ke wilayah tersebut. Para pedagang itu tidak hanya membawa misi komersial, namun ada juga yang membawa misi keagamaan. Masuknya suatu agama baru dan kemudian mendapat sambutan yang baik dari masyarakat yang disasarnya membuat masuk juga pengaruh bahasa sumber agama tersebut. Dalam agama Islam, Alquran, bacaan shalat, niat bersesuci, dan hal-hal lain yang berkaitan dengan ibadah tidak dianjurkan untuk dilafalkan dalam bahasa selain Arab. Oleh karena itu, hal ini membuat masyarakat pemeluknya terpapar bahasa Arab dengan lebih intens. Dengan demikian, muncullah efek dari peristiwa kontak bahasa ini, yaitu adanya interferensi, campur kode, dan alih kode yang terefleksi dalam penamaan tokoh dalam Hikayat Raja Pasai.

Dalam hikayat, peneliti dapat menemukan bahasa Arab yang banyak digunakan dalam penamaan diri selain bahasa sumber, yaitu bahasa Melayu. Bahasa Arab digunakan untuk menyebutkan maknamakna yang baik, sakral, dan untuk menyebut gelar sultan. Hal ini sedikit banyak menunjukkan adanya dominasi bahasa. Mackey (dalam Wijana \& Muhammad Rohmadi, 2006: 37) menyebutkan dalam teori geolinguistiknya bahwa kekuatan bahasa dapat diukur dengan sejumlah indikator, yaitu demografi, persebaran, ekonomi, ideologi, dan kultural. Indikator kultural dalam hal ini mewadahi juga ideologi, agama, politik, serta ajaran-ajaran tertentu.

Penelitian ini merupakan penelitian awal mengenai sistem penamaan tokoh-tokoh dalam Hikayat Raja Pasai. Analisis yang dikerjakan dalam artikel ini terbatas pada asal bahasa yang digunakan dalam penamaan tokohnya. Klasifikasi dan interpretasi lanjutan yang mungkin muncul dalam konstruksi penamaan tokoh dalam Hikayat Raja Pasai ini akan diperhatikan lebih mendalam dalam tesis peneliti yang akan datang.

\section{ANALISIS DAN PEMBAHASAN}

Hikayat Raja Pasai ditulis dalam aksara Jawi dan bermediumkan bahasa Melayu. Bahasa Melayu adalah anggota dari bahasa Austronesia. Menurut Collins (2011: 8) bukti tertulis bahasa Melayu Kuno digunakan di nusantara adalah dengan ditemukannya teks terkuno berbahasa Melayu Kuno bertanggal 682 di Sumatra. Mulanya, bahasa Melayu Kuno mengadaptasi ortografi India berdasarkan tulisan Palawa (tulisan India yang pernah digunakan untuk teks bahasa Sansekerta) untuk merekam 
Nadhifa Indana Zulfa Rahman

teks mereka. Tradisi ortografi tersebut dihubungkan dengan tempat suci agama yang menyebarkan ajarannya dengan tradisi tulisan tersebut (Collins, 2011: 8). I-Ching (dalam Collins, 2011: 9) menyebutkan bahwa ia menghabiskan enam bulan di Fo-shih, ibukota Sriwijaya di Sumatra untuk mempelajari bahasa Sansekerta. Lalu, ditemukan bahasa batu nisan dari abad ke-14 yang mempertahankan pola berselakan lembaran kosong dari kosakata bahasa Melayu dan Sansekerta dengan tambahan tulisan hiasan dari formula kata dan frasa bahasa Arab (Collins, 2011: 12). Pada tahun 1303, ditemukan prasasti Melayu tertua dituliskan dalam dasar ortografi bahasa Arab-disebut tulisan Jawi dalam bahasa Melayu Modern (Collins, 2011: 15). Namun demikian, meskipun ditulis dalam tulisan Jawi, istilah-istilah dalam bahasa Sansekerta tetap digunakan. Bahasa Melayu diperkaya dengan kata pinjaman dari bahasa Sansekerta dan bahasa Arab dan juga kata-kata dari bahasa-bahasa Tamil, Mongolia, Cina, Persia, dan Jawa (Collins, 2011: 15-16).

Istilah-istilah pinjaman dari bahasa lain seperti yang dipaparkan di atas juga ditemukan dalam namanama tokoh di Hikayat Raja Pasai, yaitu dari bahasa Arab (BA), bahasa Sansekerta (BS), bahasa Tamil (BT), bahasa Kawi (BK) (Jawa Kuno), bahasa Hindi (BH), bahasa Brunei (BB), dan bahasa Cina (BC). Setelah diklasifkasikan, dapat diketahui bahwa ada 10 nama menggunakan murni BA, 14 nama tokoh menggunakan murni BM, dua nama menggunakan campuran BA dan BS, satu nama menggunakan campuran BA dan BT, tujuh nama menggunakan campuran BS dan BM, dua belas nama menggunakan campuran BA dan BM, satu nama menggunakan campuran BS dan BK, satu nama menggunakan campuran BA dan modifikasi BA ke BM, empat nama menggunakan campuran BM dan BK, satu nama menggunakan campuran BK dan modifikasi dari BA ke BM, satu nama menggunakan campuran $\mathrm{BA}$ dan perpaduan $\mathrm{BH}+\mathrm{BA}$, satu nama menggunakan campuran $\mathrm{BA}$ dan perpaduan $B M+B A$, satu nama menggunakan campuran $B M$ dan modifikasi $B A$ ke $B M$, satu nama menggunakan campuran BB dan BM, satu nama menggunakan campuran BK, BS, dan BM, dua nama nama menggunakan campuran BC dan BM.

\section{Penamaan dengan Murni bahasa Arab}

Konstruksi ini ada pada nama-nama tokoh berikut ini Abu Bakar, Ibrahim Khalil, (Syeikh) Ismail, (Sultan) Malikul Mahmud, (Sultan) Malikul Mansur, (Sultan) Malikul Nasir, (Sultan) Malikul Saleh, (Sultan) Malikul Tahir, (Nabi) Muhammad, (Sultan) Muhammad. Penamaan dengan menggunakan bahasa Arab merujuk pada tokoh penting Islam, merujuk pada kata sifat, merujuk pada kedudukan sosial yang tinggi di masyarakat. Dengan demikian, dapat dikatakan bahwa yang bisa memiliki nama dengan konstruksi murni Arab adalah para pemimpin agama atau kerajaan yang semasa kepemimpinannya baik dan diteladani rakyat.

\section{Penamaan dengan Murni bahasa Melayu}

Konstruksi ini ada pada nama-nama tokoh berikut ini Barang Laksamana, Bermamat Pantai, (Si) Bintang Timur, (Bujangga) Baja Raya, (Malim) Pagar Sesah, Medana (Medan*) Pantai, Merah Hasum, Merah Silau, Orang Tikar, (Syah) Alam Kota, Tulus Agung Tukang Sukara (Sukar*), (Tun) Bijaya Pangliran, (Tun) Haria (Hari*) Jong, (Tun) Seri Kaya. Penamaan ini merujuk pada kata benda, kata tempat, flora, benda langit, kata sifat, dan gelar kebangsawanan. Sebelum memeluk agama Islam, Raja Pasai yang pertama, (Sultan) Malikul Saleh bernama Merah Silau. Merah adalah sebutan kebangsawanan Melayu, Silau adalah kata sifat yang berarti 'bercahaya hingga menyilaukan mata, misalnya oleh cahaya matahari...' (Hussain dalam Jones (1999: 92). Namun demikian, ketika menjadi raja, ia mengubah namanya dengan konstruksi murni bahasa Arab. Akan tetapi, untuk bangsawanbangsawan lain yang tidak menjadi raja, konstruksi nama dan gelar Melayunya tetap. Hal ini menunjukkan bahwa bahasa Arab menjadikan nama seorang tokoh menjadi lebih prestise atau mengasosiasikan bahwa tokoh tersebut terpandang di masanya.

\section{Penamaan dengan Campuran Bahasa Arab dan Bahasa Sansekerta}

Konstruksi ini terdapat pada (Raja) Ahmad dan (Raja) Muhammad. Gelarnya masih menggunakan raja (BS): rajan 'raja' (hlm. 235). Dua tokoh ini bersaudara dan merupakan kakek dari raja pertama Pasai yang merupakan seorang pemerintah di Sumatera Utara. Islamisasi dalam hikayat disebutkan terjadi saat raja pertama Pasai memimpin. Oleh karena itu, gelar yang digunakan masih terpengaruh bahasa Sansekerta yang berafiliasi pada agama Hindu atau agama mayoritas saat Sriwijaya memimpin nusantara. Oleh karena itu, bisa jadi, Raja Ahmad dan Raja Muhammad adalah salah satu 
strategi Pasai untuk mencitrakan kerajaan Pasai sebagai kerajaan pertama di nusantara yang memeluk agama Islam sebagai keturunan raja yang baik yang bahkan namanya terinspirasi dari nama tokoh penting agama Islam, yaitu Nabi Muhammad SAW.

\section{Penamaan dengan Campuran Bahasa Arab dan Bahasa Tamil}

Konstruksi ini ada pada nama raja terakhir Pasai, (Sultan) Ahmad Perumudal Perumal. la adalah satusatunya raja Pasai yang memiliki konstruksi nama tidak menggunakan murni bahasa Arab. Hal ini dinilai terjadi karena ia banyak berbuat lalim. la jatuh cinta pada puterinya sendiri dan membunuh puteranya yang berusaha membela kebenaran. Oleh karena itu, konstruksi penamaan (Sultan) Ahmad ini dipertahankan dengan tambahan Perumudal Perumal yang merupakan gelar hadiah dari seorang jogi ('penganut filsafat Hindu yang bertujuan utuk menyatukan diri dg tuhan melalui senam gerak badan yoga' (hlm. 3042)) dari Kerajaan Keling. Dengan demikian, bahasa Tamil seolah membawa citra yang tidak baik untuk yang memilikinya.

\section{Penamaan dengan Campuran Bahasa Sansekerta dan Bahasa Melayu}

Konstruksi ini ada pada nama-nama tokoh: (Si) Akap (Akep*) Gagah Mengangkat, (Putri) Betung, (Putri) Ganggang, (Putri) Galuh Gemerencang, Merah Gajah, Rawana Pematang, (Tun) Haria (Hari*) Benung (Benu*). Penamaan ini merujuk pada kata sifat, kata benda, kata tempat, dan kedudukan sosial yang tinggi di masyarakat. Gelar Putri (BS): 'anak perempuan' (hlm. 186) diberikan untuk para anak perempuan raja. Walapun Putri Galuh Gemerencang adalah Putri Majapahit, ia dicitrakan baik dengan adanya penambahan bahasa Melayu di namanya. Oleh karena ia mencintai anak dari (Sultan) Ahmad Perumudal Perumal, ia akhirnya harus meninggal karena ulah (Sultan) Ahmad Perumudal Perumal tersebut yang cemburu pada putranya sendiri.

\section{Penamaan dengan Campuran Bahasa Arab dan Bahasa Melayu}

Konstruksi penamaan ini dapat ditemukan dari: (Si) Ali Kecil Pahat Putar, (Dara) Zulaikha Tingkap, Malik Sulaiman Dendang Air, (Malim) Zainal Belatap, Talak Sejang (Sajang*), (Tun) Abdul Jalil, (Tun) Abdul Fadil, (Tun) Fatimah Lempau (Lampau*), (Tun) Takiah Dara, Wasat Makam, Wasat Perak. Penamaan ini merujuk pada kesamaan dengan tokoh penting agama Islam, kata benda, kata sifat, dan gelar kebangsawanan yang menunjukkan kedudukan sosial di masyarakatnya. Tun adalah gelar kebangsawanan Pasai yang dilekatkan pada putera dan puteri raja. Hal ini berbeda dengan bahasa Arab yang membedakan gelar berdasarkan gender, misalnya Sultan dan Sultanah, atau dalam tradisi Jawa Raden Mas dengan Raden Ayu.

\section{Penamaan dengan Campuran Bahasa Sansekerta dan Bahasa Kawi}

Konstruksi penamaan ini dapat ditemukan satu-satunya pada (Patih) Gajah Mada. Tanpa campuran Melayu atau Arab, nama dengan konstruksi bahasa Sansekerta dan bahasa Kawi diasosiasikan untuk orang yang tidak baik atau tokoh antagonis. Seperti diketahui melalui hikayat, Kerajaan Pasai runtuh setelah diserang Majapahit. Sekalipun Gajah Mada adalah pembesar di Majapahit, dia diceritakan sebagai tokoh antagonis di hikayat ini. Oleh karena itu, tokoh-tokoh yang dicitrakan baik dalam hikayat ini tidak ada yang menggunakan konstruksi murni bahasa Sansekerta, bahasa Kawi, bahasa Tamil, dan bahasa Hindi. Bahasa-bahasa itu masih dikaitkan dengan agama terdahulu masyarakat, yaitu agama Hindu/ Buddha, yang telah ditinggalkan masyarakatnya dan kemudian memeluk agama Islam.

\section{Penamaan dengan Campuran Bahasa Arab dan Modifikasi Bahasa Arab ke Bahasa Melayu}

Konstruksi ini ditemukan pada nama Malik Akasan. Akasan (dari kata Akhsan*) (BA $\rightarrow$ BM): يُحِْنُ 'berbuat baik, melakukan dengan baik, melampaui, mengetahui dengan baik'. Penamaan ini merujuk pada sifat dan kedudukan sosialnya di masyarakat. la adalah seorang hulubalang Pasai dan yang setia membantu Tun Beraim Bapa saat ia diracun ayahnya sendiri, yaitu (Sultan) Ahmad Perumudal Perumal.

\section{Penamaan dengan Campuran Bahasa Melayu dan Bahasa Kawi}

Konstruksi ini terdapat pada nama nama berikut ini: (Megat) (Meget*) Kedah, (Patih) Ketemenggungan, (Patih) Suatang, Perman (Permana*) Isap. Penamaan tersebut mengacu pada lokasi, kata bilangan, kata kerja, merujuk pada gelar yang menandai kedudukan sosialnya di 
Nadhifa Indana Zulfa Rahman

masyarakat. Misalnya kata Megat (Meget*) (BK): orang-orang penting' (hlm. 225) Kedah (BM): 'nama tempat'. la merupakan salah satu tokoh yang mendukung pengukuhan Merah Silau (Malikul Saleh) menjadi raja.

\section{Penamaan dengan Campuran Bahasa Kawi dan Modifikasi Bahasa Arab ke Bahasa Melayu}

Konstruksi ini terdapat pada nama Megat (Meget*) Sekandar. Megat (Meget*) (BK): orang-orang penting' (hlm. 225) Sekandar (BA $\rightarrow$ BM): terinspirasi dari Sultan Iskandar Zulkarnain. la dan saudaranya (Megat) (Meget*) Kedah menjadi tokoh yang mendukung pengukuhan Merah Silau (Malikul Saleh) menjadi raja.

\section{Penamaan dengan Campuran Bahasa Arab dan Perpaduan Bahasa Hindi serta Bahasa Arab}

Konstruksi ini terdapat pada nama tokoh menteri di Pasai, (Sayid) Ali Ghiatuddin. Ali merupakan nama yang sama dengan sahabat dan menantu Nabi Muhammad SAW yang juga menjadi khalifah Islam ke empat. Ghiyath (BH) + Addin (BA): घियत ghiyath 'ketebalan' + الدين 'agama' nama ini populer di Delhi, tetapi tidak di tanah melayu (Winstedt via Jones, 95), sedangkan Sayid berasal dari bahasa Arab سيد yang artinya 'tuan, raja, ketua, kepala, baginda'. Penamaan ini mengacu pada sifat, kedudukan sosial yang tinggi di masyarakat, dan megandung doa/ harapan.

\section{Penamaan dengan Campuran Bahasa Arab dan Perpaduan Bahasa Melayu serta Bahasa Arab}

Konstruksi ini terdapat pada nama tokoh menteri di Pasai bersama (Sayid) Ali Ghiatuddin yaitu (Sayid) Semayamuddin. Sayid berasal dari bahasa Arab (BA): سيد yang artinya 'tuan, raja, ketua, kepala, baginda', sedangkan Semayam berasal dari bahasa Melayu (BM) yang artinya 'duduk di atas takhta atau singgasana' (hlm. 2446) ditambah kata Addin dari bahasa Arab (BA)') الدين yang berarti 'agama'. Penamaan ini mengacu pada sifat, kedudukan sosial yang tinggi di masyarakat, dan megandung doa/ harapan.

\section{Penamaan dengan Campuran Bahasa Melayu dan Modifikasi Bahasa Arab ke Bahasa Melayu}

Konstruksi ini terdapat pada tokoh wira/ kesatria sesungguhnya dari Pasai, (Tun) Beraim Bapa. Dia adalah anak tertua (Sultan) Ahmad Perumudal Perumal. Tokoh ini bergelar Tun yang merupakan gelar kehormatan di Pasai. Beraim (BM modifikasi dari BA): menurut Jones via Wilkinson, (tahun:98) Beraim (seperti Berahim) adalah singkatan bagi Ibrahim yang juga dikuatkan dalam De Hikajat Atjeh edisi Teuku Iskandar yang menyebut Ibrahim Khalil (Ibrahim "Sahabat Allah") dengan Beraim Khalil) dan Bapa (BM): 'Panggilan kepada laki-laki yang tua sbg tanda hormat' (hlm. 234). Penamaan ini merujuk pada kesamaan dengan tokoh penting Islam, kedudukannya dalam silsilah keluarga, dan kedudukannya di sosial masyarakat.

\section{Penamaan dengan Campuran Bahasa Brunei dan Bahasa Melayu}

Konstruksi ini terdapat pada nama puteri (Sultan) Ahmad Perumudal Perumal yang sekaligus juga menjadi perempuan yang dicintai ayahnya sendiri, (Tun) Medam (Madam*) Peria. Medam (Madam*) (BB): 'berpusing ligat, silih berganti peminjamnya, kerap berjalan dari satu tempat ke tempat lainnya (hlm. 1671), sedangkan Peria (BM): 'tumbuhan menjalar, bunganya kecil-kecil berwarna kuning' (hlm.2058). penamaan ini merujuk pada kata kerja, flora, dan gelarnya sebagai bangsawan pasai yang menunjukkan kedudukan sosial masyarakatnya di masa itu.

\section{Penamaan dengan Campuran Bahasa Kawi, Bahasa Sansekerta, dan Bahasa Melayu}

Konstruksi ini muncul pada seorang hulubalang yang dikirim Putri Galuh Gemerencang dari Majapahit untuk mencari calon suami, (Tun) Perpatih (Patih*) Jena (Jina*). Namun demikian, hulubalang ini memiliki penambahan bahasa Melayu pada gelar di dalam konstruksi namanya. Hal itu karena dia citranya baik, walaupun namanya mengandung nama bagi seorang Buddha. Konstruksinya adalah $\rightarrow$ Tun (BM): gelar kehormatan Pasai (Jones, 96); Perpatih (Patih*) (BK): 'mangkubumi; orang yang dipercaya; pamatih kepatuhan' (hlm. 171); dan Jena (Jina*) (BS): 'nama bagi Buddha' (hlm. 110). 


\section{Penamaan dengan Campuran Bahasa Cina dan Bahasa Melayu}

Konstruksi ini dapat ditemukan dalam nama dua tokoh yaitu (Baba) Mentuha (mentua*) dan (Tun) Baba Kaya. Keduanya merupakan tokoh yang dicitrakan baik dalam hikayat ini. Konstruksinya ialah $\rightarrow$ Baba (BC): 爸爸 'segolongan orang Cina di Malaya yang bertutur dalam bahasa Melayu sebagai bahasa pertamanya dan mengamalkan cara hidup orang Melayu' (hlm. 176) dan Mentua* (BM): 'mertua' (hlm. 1767).

Bahasa Arab dan bahasa Melayu seolah dicitrakan untuk hal-hal yang baik atau terpuji. Hal ini dapat dilihat dari konstruksi nama tokoh utama, tokoh-tokoh bangsawan, tokoh-tokoh lain yang citranya agung, baik, dan terpuji adalah dengan menambahkan bahasa Arab atau bahasa Melayu atau modifikasinya dalam konstruksi penamaannya. Hal ini berbeda dengan nama tokoh-tokoh yang menggunakan bahasa Sansekerta, bahasa Kawi, bahasa Tamil, atau juga bahasa Hindi yang tidak mendapatkan tambahan konstruksi bahasa Melayu atau Arab. Nama-nama tersebut dipertahankan untuk mereka yang antagonis atau tercela sifat dan perilakunya.

\section{KESIMPULAN}

Pasai adalah kerajaan nusantara pertama yang memeluk agama Islam. Dengan demikian, tidak dapat dipungkiri jika masyarakat Pasai juga terpapar bahasa Arab. Dalam ajaran Islam, kitab suci Al-quran tidak boleh diterjemahkan tanpa menyertakan teks aslinya, yaitu dalam bahasa Arab. Hal itu ditujukan untuk menjaga keasliannya. Selain itu, membaca Al-quran pun tidak boleh hanya artinya. Dengan demikian, belajar agama Islam otomatis mengharuskan pemeluknya untuk belajar minimal membaca huruf hijaiyah. Untuk dapat memahami makna bacaan ketika ibadah salat misalnya, seorang muslim harus belajar tata bahasa bahasa Arab. Dengan dominannya penggunaan bahasa Arab dalam ritual religi yang tidak lepas dari keseharian masyarakat menjadikan pengaruh bahasa Arab mulai menyebar di masyarakat. Bahasa kitab suci atau bahasa Arab dianggap kultus dan sakral sehingga penuturnya akan terlihat lebih berwibawa jika menggunakannya dalam pengucapan.

Kebanggaan untuk memunculkan identitas diri sebagai pemeluk agama juga kerap ingin ditampilkan. Salah satu caranya adalah melalui penamaan diri. Perubahan identitas tokoh yang semula memeluk agama Hindu/ Buddha karena sisa-sisa pengaruh kerajaan terdahulu, seperti Sriwijaya dan Kalingga, tampak pada perubahan nama yang semula menggunakan konstruksi bahasa Melayu, Sansekerta, atau bahasa lainnya menjadi bahasa Arab atau modifikasinya. Bahasa Arab dinilai lebih prestise dibandingkan bahasa-bahasa yang lain. Hal ini bisa dilihat pada penamaan tokoh yang murni menggunakan bahasa Arab adalah tokoh-tokoh yang dalam hal agama maupun politik memiliki kedudukan tinggi dan citra yang bagus. Akan tetapi, tokoh lain, walaupun ia adalah Raja Pasai, karena citranya buruk selama masa kepemimpinan, konstruksi penamaan dirinya dicampur dengan bahasa Tamil. Bahasa Melayu juga menjadi bahasa yang prestise walaupun kadarnya ada satu tingkat di bawah bahasa Arab karena bahasa Melayu digunakan dalam penamaan para bangsawan walaupun bukan untuk raja di Pasai. Selain itu, frekuensi penggunaan konstruksi penamaan dengan murni bahasa Melayu ini adalah yang tertinggi, yaitu empat belas tokoh. Lalu, untuk bahasa Sansekerta, bahasa Kawi (Jawa Kuno), bahasa Hindi, bahasa Brunei digunakan untuk tokoh-tokoh yang lain yang porsi penceritaannya tidak banyak walaupun gelar atau pangkat bangsawannya tinggi. Dengan demikian, dapat dikatakan bahwa bahasa Arab dinilai lebih prestise dibanding bahasa-bahasa yang lain. Oleh karena itu, agama juga berperan dalam penyebaran bahasa dan kemudian memengaruhi cara masyarakat memandang dan melabeli realitas sosialnya. Hal itu dapat dilihat dari penamaan tokoh seperti yang telah dipaparkan di atas.

\section{DAFTAR PUSTAKA}

Ariwibowo, Eric Kunto. 2016. "Pemilihan Nama Arab sebagai Strategi Manajemen Identitas di antara Keluarga Jawa Muslim" dalam Proceeding International Seminar Prasasti III. Cetakan 1, Hlm. $270-277$.

Baroroh-Baried, Siti dkk. 1994. Pengantar Teori Filologi. Yogyakarta: Badan Penelitian dan Publikasi Fakultas (BPPF), Seksi Filologi, Fakultas Sastra, Universitas Gadjah Mada

Blanár, Vincent. 2009. Proper Names in The Light of Theoretical Onomastics. Slowakia: Matica Slovenská. 
Nadhifa Indana Zulfa Rahman

Clifford, Hugh and Frank Athelstane Swettenham. 1894. A Dictionary of The Malay Language MalayEnglish. Taping: The Government Printing Office.

Collins, James T. 2011. Bahasa Melayu Bahasa Dunia. Jakarta: Yayasan Pustaka Obor Indonesia.

Jones, Russell. 1999. Hikayat Raja Pasai. Kuala Lumpur: Yayasan Karyawan dan Penerbit Fajar Bakti.

Liaw Yock Fang. 1975. Sejarah Kesusastraan Melayu Klasik. Singapura: Pustaka Nasional.

Sariah. 2012. "Antroponimi dalam Obituari Keturunan Tionghoa: Sebuah Tinjauan Deskriptif" dalam Metalingua. Vol. 12, Hlm. 185-194.

Siswanto. 2012. "Pengulangan Bunyi Nama Diri pada Masyarakat Sunda" dalam Metalingua. Vol. 10, HIm. 65一72.

Tim Penyusun. 2003. Kamus Bahasa Melayu Nusantara. Brunei: Dewan Bahasa dan Pustaka Kementerian Kebudayaan, Belia, dan Sukan.

Wibowo, Ridha Mashudi. 2001. "Nama Diri Etnik Jawa" dalam Humaniora. Vol. XIII, Hlm. 45-55.

Wojowasito, Soewojo. 1970. Kamus Kawi (Djawa Kuno)_Indonesia. Malang: Team Publikasi Ilmiah Fakultas Keguruan Sastra \& Seni IKIP Malang.

\section{DAFTRA LAMAN}

kbbi.kemdikbud.go.id diakses pada 17 Juni 2019.

www.almaany.com diakses pada 17 Juni 2019.

glosbe.com diakses pada 17 Juni 2019.

hindi-english.org diakses pada 17 Juni 2019. 